\title{
Electromyographic assessment of masticatory muscles activity in patients with severe alveolar bone atrophy with implant-supported fixed dental prostheses
}

\author{
R. R. Ilyk ${ }^{1}$, O. F. Sirenko², M. O. Pavlenko² \\ ${ }^{1}$ Danylo Halytsky Lviv National Medical University, Lviv, Ukraine, ${ }^{2}$ Shupyk National Medical Academy of Postgraduate Education, Kyiv, Ukraine
}

Objective - to assess masticatory muscles activity in patients with denture defects and severe alveolar bone atrophy in posterior maxillae rehabilitated by implant-supported fixed dental prostheses in different terms of treatment according to provided technique.

Materials and methods. The effectiveness of prosthetic treatment with implant-supported fixed dental prostheses (FDP) and electromyographic (EMG) assessment of masticatory muscles activity were studied among 67 patients, who were treated between 2012 and 2017. There were 29 (43.3\%) men and 38 (56.7 \%) women; the average age of patients was $35.7 \pm 12.0$ years. All patients had one- or two-sided terminal dentition defects in posterior maxillary region without severe periodontal or general pathology. Prosthetic treatment was performed on root-form osseointegrated dental implants with a screw design. Partially dentate patients were divided into three study groups depending on treatment method provided. The functional activity of masticatory muscles was detected.

Results. Comparative assessment of the masticatory muscles functional activity changes in patients with severe bone atrophy of posterior maxillae after different methods of prosthetic treatment by implant-supported fixed dental prostheses was performed. The retrieval rate of masticatory muscles functional activity in patients with severely atrophied posterior maxillae depends on the terms of orthopedic rehabilitation and explicit timing of implant-supported dental prostheses application. The increase in bioelectrical activity values and asymmetry of masticatory muscles activity reduction in case of osteotome sinus floor elevation with lateral approach by means of atraumatic technique and simultaneous implant insertion as well as in case of direct short implants placement testify strong tendency to normalization of functional masticatory activity, needed for appropriate prosthetic rehabilitation of dentate patients.

Conclusions. Osteotome sinus floor elevation with lateral approach by means of atraumatic technique and direct implant insertion into crestal bone in dentate atrophic posterior maxillae provides favourable conditions for rapid normalization of masticatory activity in comparison with the conventional treatment. Short-length implants are proved as acceptable alternative to sinus lifting procedures and have both clinical and financial advantages.

\section{Електроміографічне оцінювання функціональної активності жувальних м'язів у пацієнтів при значній атрофії альвеолярних відростків щелеп з ортопедичними конструкціями з опорою на дентальні імплантати}

\section{Р. Р. Ілик, О. Ф. Сіренко, М. О. Павленко}

Мета роботи - оцінити активність жувальних м'язів пацієнтів із десректами зубних рядів і вираженою атрофією кісткової тканини в дистальному відділі верхньої щелепи, реабілітованих незнімними зубними протезами з опорою на імплантати, у різні строки спостереження відповідно до застосованих методик.

Матеріали та методи. Визначили ефективність ортопедичного лікування незнімними зубними протезами на імплантатах та здійснили електроміографічне оцінювання активності жувальних м'язів 67 хворих, які отримували лікування з 2012 до 2017 року. Чоловіків було 29 (43,3\%), жінок - 38 (56,7 \%), середній вік пацієнтів - 35,7 $\pm 12,0$ року. Усі пацієнти були з одно- чи двобічними кінцевими дефектами зубних рядів у боковій ділянці верхньої щелепи без вираженої патології пародонта або загальної патології. Ортопедичне лікування здійснювали на остеоінтегрованих гвинтових коренеподібних імплантатах. Пацієнтів із дефектами зубних рядів поділили на 3 групи відповідно до обраного методу лікування. Визначили функціональну активність жувальних м'язів.

Результати. Здійснили порівняльне оцінювання змін функціональної активності жувальних м'язів у пацієнтів із вираженою атрофрією дистального відділу верхньої щелепи після застосування різних методів ортопедичного лікування незнімними ортопедичними конструкціями з опорою на імплантати. Швидкість відновлення функціональної активності жувальних м'язів у пацієнтів із вираженою атрофією дистального відділу верхньої щелепи залежить від строків ортопедичної реабілітації та часу встановлення протезів з опорою на імплантати. Зростання показників біоелектричної активності та зменшення асиметрії в активності жувальних м'язів у випадку відкритого синус-ліфтингу з боковим доступом за атравматичною технікою та одночасним встановлення імплантатів, як і у випадку безпосереднього встановлення коротких імплантатів, підтверджує виражену тенденцію до нормалізації функціональної активності жувальних м'язів, що необхідна для належної ортопедичної реабілітації пацієнтів із десректами зубних рядів.

Висновки. Відкритий синус-ліфтинг з боковим доступом за атравматичною технікою та одночасним встановленням імплантатів у дистальний відділ беззубої атрофованої верхньої щелепи забезпечує сприятливі умови для швидшої нормалізації активності жувальних м'язів порівняно з традиційним лікуванням. Короткі імплантати є прийнятною альтернативою процедур синус-ліфтингу та мають клінічні та фінансові переваги.
Key words: dental prostheses, implants, masticatory muscles, sinus floor augmentation, functional loading.

\section{Zaporozhye} medical journal 2018; 20 (4), 557-561 Dol: $10.14739 / 2310-1210$ 2018.4.135823

E-mail: sirenko_a@ukr.net
Ключові слова: зубні протези, імплантати, жувальні м'язи, синус-міфтинг, функціональне навантаження.

Запорізький медичний журнал. - 2018. T. 20, № 4(109). C. 557-561 
Ключевые слова: зубные протезы, имплантаты, жевательные мышцы, синус-лифтинг, функциональная нагрузка.

Запорожский медицинский журнал. - 2018. T. 20, № 4(109). C. 557-561

\section{Экектромиографическая оценка функциональной активности жевательных мышц у пациентов при выраженной атрофии альвеолярных отростков челюстей с зубными протезами на имплантатах}

\section{Р. Р. Илык, А. Ф. Сиренко, М. А. Павленко}

Цель работы - оценить активность жевательных мышц у пациентов с десектами зубных рядов и выраженной атрофией кости в дистальном отделе верхней челюсти, реабилитированных несъемными зубными протезами с опорой на имплантаты, в разные сроки наблюдения соответственно примененных методик.

Материалы и методы. Изучили эффективность ортопедического лечения несъемными зубными протезами на имплантатах и провели электромиографрическую оценку активности жевательных мышц 67 больных, которые проходили лечение с 2012 по 2017 год. Мужчин было 29 (43,3 \%), женщин - 38 (56,7 \%), средний возраст пациентов - 35,7 $\pm 12,0$ года. Все пациенты были с одно- или двухсторонними конечными дефектами зубных рядов в боковом участке верхней челюсти без выраженной патологии пародонта или общей патологии. Ортопедическое лечение проводили на остеоинтегрированных винтовых корневидных имплантатах. Пациентов с дефектами зубных рядов поделили на 3 группы соответственно выбранному методу лечения. Определяли функциональную активность жевательных мышц.

Результаты. Проведена сравнительная оценка изменений функциональной активности жевательных мышц у пациентов с выраженной атрофией дистального отдела верхней челюсти после применения разных методов ортопедического лечения несъемными ортопедическими конструкциями с опорой на имплантаты. Скорость восстановления функциональной активности жевательных мышц у пациентов с выраженной атрофией дистального отдела верхней челюсти зависит от сроков ортопедической реабилитации и времени установки протезов с опорой на имплантаты. Возрастание показателей биоэлектрической активности жевательных мышц в случае открытого синус-лифтинга с боковым доступом по атравматической технике с одновременной установкой имплантатов, как и в случае непосредственной установки коротких имплантатов, подтверждает выраженную тенденцию к нормализации фрункциональной активности жевательных мышц, необходимой для надлежащей ортопедической реабилитации пациентов с дефектами зубных рядов.

Выводы. Открытый синус-лифртинг с боковым доступом по атравматической технике с одновременной установкой имплантатов в дистальном отделе беззубой атрофированной верхней челюсти обеспечивает благоприятные условия для скорейшей нормализации активности жевательных мышц по сравнению с традиционным лечением. Короткие имплантаты являются приемлемой альтернативой процедур синус-лифтинга и имеют клинические и финансовые преимущества.

\section{Introduction}

Bone atrophy is one of the most common consequences of tooth loss in edentulous or partially dentate posterior maxillae. Prosthetic treatment of patients with severely atrophic posterior maxillae is extremely difficult, requiring provision of additional bone augmentation. Though the outcome of conventional osteotome sinus floor elevation (OSFE) is difficult to predict [1].

Much uncertainty still exists about maxillary augmentation with and without bone grafting. Sinus bone reformation in comparison with the conventional technique of sinus lifting with filling material has shown several advantages: a lower infection risk due to the absence of biomaterial, reduced cost, simpler technique and better patients' acceptance [2].

A considerable amount of literature has been published on minimally invasive antral membrane balloon elevation. Studies reported predictable results of this procedure, providing the opportunity of simultaneous implant placing. Particularly, data from research by Brizuella et al. (2014) proved the minimally invasive sinus lifting balloon technique to be a promising method in achieving required bone height enabling implant insertion in atrophied posterior maxilla [3]. Notwithstanding safety and effectiveness of such minimally invasive procedures, the timing of implant placement is still debated because of the lack of primary stability for proper osteointegration.

Debate continues about the best method of implant insertion (delayed or simultaneous) with following nonfunctional and functional occlusal loading. Cara-Fuentes et al. (2016) came to conclusion that it is necessary to understand the intrasinus bone-formation process, specifically timing, quantity and arrangement determining when an implant can receive total functional loading and optimal number and implants disposition in each particular clinical situation [2]. Delayed implant was deemed as ensuring adequate graft maturation [3].

At present, it is admitted that the use of short-length implants may avoid the need for complicated bone augmentation procedures [4], reducing time and cost of treatment. Studies over the past few years have proved the possibility of short implant placement and have confirmed its clinical effectiveness in comparison with the conventional treatment with sinus augmentation [5-7]. It was stated that the use of short implants might avoid adjunct procedures used for implant insertion, thereby reducing operative time, complexity and postoperative discomfort [8].

The purpose of this research was to study different methods of prosthetic rehabilitation clinical effectiveness in partially dentate patients with severely atrophied posterior maxilla using implant-supported fixed dental prostheses.

\section{Objective}

The specific objective of this study was to assess masticatory muscles activity of partially dentate patients with severe alveolar bone atrophy in posterior maxillae rehabilitated by implant-supported fixed dental prostheses in different terms of treatment according to provided technique. 


\section{Materials and methods}

The effectiveness of prosthetic treatment with implantsupported FDP and electromyographic assessment of masticatory muscles activity were studied among 67 patients, who were treated between 2012 and 2017 at the Department of Dentistry of the Shupyk National Medical Academy of Postgraduate Education, Kyiv, Ukraine. There were $29(43.3 \%)$ men and 38 (56.7 \%) women; the average age of patients was $35.7 \pm 12.0$ years.

All patients had one- or two-sided terminal dentition defects in posterior maxillary region. There were no periodontal diseases and no severe general pathology diagnosed in patients of studied groups. An intraoral examination was conducted by using a mouth mirror and probe without removing fixed prostheses. Prosthetic treatment was performed on root-form osseointegrated dental implants with a screw design. Implant stability was studied by frequency-resonance analysis measuring Implant Stability Quotient (ISQ) ("Osstell ISQ") and the level of marginal bone loss was determined radiologically (radiovisiography, computer tomography). Surface EMG was performed to assess functional activity of masticatory muscles for measuring the effectiveness of prosthetic treatment by computer neuro-electromyograph "M-Test" (DX Systems, Kharkiv, Ukraine) [10]. The masticatory muscles bioelectrical activity was determined by electromyographic parameters: average amplitude of voluntary clenches (AAVC), average amplitude of mastication (AAM), duration of activity phase (AP), duration of rest phase (RP) and activity/rest phase ratio $(\mathrm{K})$.

The control group included 10 patients of the same age with intact dental arches and dental prophylaxis.

Partially dentate patients were divided into three study groups.

The first group included 22 patients with implant insertion simultaneously with sinus augmentation. OSFE with lateral approach was performed by means of atraumatic sinus lifting kit with synthetic bone graft material to preserve crystal bone in the implant site, allowing simultaneous implant insertion. Provisional restorations were used in 3 month after implant placement. The provisional restorations were changed into cemented metalloceramic or ceramic crowns after 3-month nonfunctional loading.

The second group included 23 partially dentate patients, underwent conventional OSFE with delayed implant insertion in 6 month after sinus lifting. Cemented metalloceramic or ceramic functional loaded implant supported restorations were placed in 9 month after sinus augmentation. No provisional restorations were used.

The third group involved 22 patients with direct placement of short implants without any bone graft procedures. Prosthetic treatment was analogous to that of the first group: provisional restorations were used in 3 month after implant placement, changed into cemented metalloceramic or ceramic crowns after 3-month nonfunctional loading.

Data for this study were collected by statistical analysis on a personal computer using MS Excel 10 and Statistica 6.0 for Windows (StatSoft Inc, USA). Results were presented as arithmetic mean value (M) and the standard error of the mean $(\mathrm{m})$ using Student's test. Differences between the data were considered to be statistically significant at a value of $\mathrm{P}<0.05$.

\section{Results and discussion}

The effectiveness of prosthetic treatment with implantsupported FDP and electromyographic assessment of masticatory activity were studied among 67 patients, who were treated between 2012 and 2017. Average ISQ values after placement of implants were $70.58 \pm 3.02$ and did not show reliable difference in patients of studied groups. Assessment during the follow-up period ( 6 and 12 months after implant insertion) demonstrated similar average ISQ values (66.89 \pm 1.71 and $68.36 \pm 2.21$, respectively). The possibility of prosthetic treatment was confirmed by the frequency-resonance analysis results proving the fact of implant osteointegration. Obtained data correspond to results stated by other studies $[8,10]$.

Electromyographic studies (surface EMG) in all studied groups were performed before treatment, 6 and 12 months after implant insertion.

High-amplitude oscillations of approximately equal biopotentials and inclusion of large number of motor units during 3-second voluntary dental clenching test were revealed in patients of control group. AAVC of masticatory muscles was detected $(649.0 \pm 12.7$ and $612.0 \pm 14.1$ on the right and left sides, respectively). During the mastication probe well-defined alternation of bioelectrical activity and rest periods was observed in the control group. Oscillation amplitude gradually increased in the middle of biopotential lowering to its end. The duration of activity phase (AP) and rest phase (RP) in patients with intact teeth were approximately equal. The ratio of activity and rest phase (K) was defined as $1.08 \pm 0.05$ and $1.06 \pm 0.11$ on the right and left sides, respectively.

Significant changes in masticatory muscles functional activity in partially dentate patients of study groups were determined by electromyographic assessment before treatment in comparison with the control group results.

The decrease in biopotential amplitude of masticatory muscles on the side of dentition defect was observed during 3-second voluntary clenching test without reliable discrepancies between patients of all sdudy groups. On average, bioelectrical activity of masticatory muscles was low among all partially dentate patients in the first (AAVC: $537.0 \pm 15.3 \mu \mathrm{V}$ and $521.00 \pm 12.51 \mu \mathrm{V}$ on the right and left sides, respectively; AAM: $591.00 \pm 4.51 \mu \mathrm{V}$ and $580.00 \pm 2.35 \mu \mathrm{V}$ on the right and left sides, respectively), in the second (AAVC: $413.0 \pm 18.1 \mu \mathrm{V}$ and $409.0 \pm 9.4 \mu \mathrm{V}$ on the right and left sides, respectively; AAM: $478.0 \pm 13.2 \mu \mathrm{V}$ and $492.0 \pm 12.8 \mu \mathrm{V}$ on the right and left sides, respectively) and in the third (AAVC: $573.0 \pm 8.6 \mu \mathrm{V}$ and $584.0 \pm 9.3 \mu \mathrm{V}$ on the right and left sides, respectively; AAM: $610.0 \pm 8.1 \mu \mathrm{V}$ and $601.0 \pm 11.3 \mu \mathrm{V}$ on the right and left sides, respectively) groups. The expression of changes in masticatory muscles functional activity depended on proximity and duration of such dentition defects existence.

The ratio of activity and rest phase $(K)$ was defined in all study groups with significantly higher coefficients in the first $(1.25 \pm 0.02$ and $1.37 \pm 0.03$ on the right and left sides, respectively), the second ( $1.38 \pm 0.05$ and $1.47 \pm 0.03$ 
on the right and left sides, respectively, and the third $(1.31 \pm 0.01$ and $1.32 \pm 0.04$ on the right and left sides, respectively) groups in comparison with the control group $(P<0.05)$ at the beginning of treatment.

During early follow-up period (6 months after implant insertion) mean values of masticatory muscles bioelectrical activity were higher in the first (AAVC: $587.00 \pm 12.21 \mu \mathrm{V}$ and $567.0 \pm 12.7 \mu \mathrm{V}$ on the right and left sides, respectively; AAM: $699.00 \pm 7.11 \mu \mathrm{V}$ and $658.00 \pm 5.12 \mu \mathrm{V}$ on the right and left sides, respectively) and the third (AAVC: $591.0 \pm 10.1 \mu \mathrm{V}$ and $603.0 \pm 6.9 \mu \mathrm{V}$ on the right and left sides, respectively; AAM: $657.0 \pm 11.2 \mu \mathrm{V}$ and $632.0 \pm 5.6$ $\mu \mathrm{V}$ on the right and left sides, respectively) groups in comparison with the second group (AAVC: $497.0 \pm 12.6 \mu \mathrm{V}$ and $463.0 \pm 11.5 \mu \mathrm{V}$ on the right and left sides, respectively; AAM: $596.0 \pm 17.5 \mu \mathrm{V}$ and $565.00 \pm 10.09 \mu \mathrm{V}$ on the right and left sides, respectively) $(P<0.05)$. The lowest values of AAVC in the second group indicate decreased functional activity of masticatory muscles. There was no statistically significant difference between mean values in the first and the second study groups.

Mean values of masticatory muscles bioelectrical activity in all study groups exceeded mean values of bioelectrical rest, confirmed by means of the activity and rest phase ratio (K). Significant differences of activity/ rest phase ratio were observed in the second group (1.22 and 1.21 on the right and left sides, respectively) in comparison with the first (1.14 and 1.17 on the right and left sides, respectively) and the third (1.12 and 1.13 on the right and left sides, respectively) groups $(\mathrm{P}<0.05)$.

In 12 months after implant insertion the lowest mean values of masticatory muscles bioelectrical activity were revealed in the second group with conventional treatment and delayed implantation (AAVC: $528.0 \pm 9.2 \mu \mathrm{V}$ and $515.0 \pm 11.8 \mu \mathrm{V}$ on the right and left sides, respectively; AAM: $614.0 \pm 11.8 \mu \mathrm{V}$ and $607.0 \pm 10.4 \mu \mathrm{V}$ on the right and left sides, respectively) in comparison with the first (AAVC: $626.0 \pm 13.6 \mu \mathrm{V}$ and $599.0 \pm 3.7 \mu \mathrm{V}$ on the right and left sides, respectively; AAM: $712.00 \pm 13.15 \mu \mathrm{V}$ and $695.0 \pm 11.1 \mu \mathrm{V}$ on the right and left sides, respectively), the third (AAVC: $634.00 \pm 11.87 \mu \mathrm{V}$ and $607.0 \pm 7.1 \mu \mathrm{V}$ on the right and left sides, respectively; AAM: $703.0 \pm 8.7 \mu \mathrm{V}$ and $689.0 \pm 5.6 \mu \mathrm{V}$ on the right and left sides, respectively) and control (AAVC: $649.0 \pm 12.7 \mu \mathrm{V}$ and $612.0 \pm 14.1 \mu \mathrm{V}$ on the right and left sides, respectively; AAM: $725.0 \pm 19.6 \mu \mathrm{V}$ and $684.0 \pm 13.6 \mu \mathrm{V}$ on the right and left sides, respectively) groups $(P<0.05)$. During this period the ratio of activity and rest phase $(K)$ descended faster in the first $(1.10 \pm 0.09$ and $1.10 \pm 0.01$ on the right and left sides, respectively) and the third $(1.09 \pm 0.02$ and $1.09 \pm 0.01$ on the right and left sides, respectively) study groups in comparison with the second group $(1.18 \pm 0,04$ and $1.19 \pm 0.03$ on the right and left sides, respectively) $(P<0.05)$. An increase in the values of bioelectrical activity and reduction in asymmetry of masticatory muscles activity in the first and the third groups testifies strong tendency to normalization of functional masticatory activity needed for appropriate prosthetic rehabilitation of partially dentate patients. It should be noted that functional activity of masticatory muscles in the second group with the conventional treatment has not been restored completely, though having positive dynamics. Obtained EMG values correspond to previous study results $[9,10]$.

\section{Conclusions}

1. Comparative assessment of changes in the masticatory muscles functional activity in patients with severe bone atrophy of posterior maxillae after different methods of prosthetic treatment by implant-supported fixed dental prostheses was performed.

2. The retrieval rate of masticatory muscles functional activity in patients with severely atrophied posterior maxillae depends on the terms of orthopedic rehabilitation and explicit timing of implant-supported dental prostheses application.

3. Osteotome sinus floor elevation with lateral approach by means of atraumatic technique accompanied by direct implant insertion into crestal bone in dentate atrophic posterior maxillae provides favourable conditions for rapid normalization of masticatory activity in comparison with the conventional treatment.

4. Short-length implants are proved as acceptable alternative to sinus lifting procedures and have both clinical and financial advantages.

The perspective for the further scientific researches: obtained results indicate the possibility of short implants placement without sinus augmentation in case of atrophied posterior maxillae, although timing of functional loading and peculiarities of its distribution on implant-supported dental prostheses need further research.

Conflicts of Interest: authors have no conflict of interest to declare. Конфлікт інтересів: віАсутній.

Information about authors:

llyk R. R., MD, PhD, DSc, Professor, Department of Prosthetic Dentistry, Danylo Halytsky Lviv National Medical University, Ukraine.

Sirenko O. F., MD, PhD, Associate Professor, Department of Dentistry, Shupyk National Medical Academy of Postgraduate Education, Kyiv, Ukraine. http://orcid.org/0000-0002-7923-8534 http://www.researcherid.com/rid/J-6760-2016

Pavlenko M. O., MD, PhD, Associate Professor, Department of Dentistry, Shupyk National Medical Academy of Postgraduate Education, Kyiv, Ukraine.

Відомості про авторів:

Ілик Р. Р., А-р меА. наук, професор каф. ортопедичної стоматології, Аьвівський національний меАичний університет імені Аанила Галицького, Україна.

Сіренко О. Ф., канА. меА. наук, Аоцент каф. стоматології, Національна медична академія післядипломної освіти імені П. А. Шупика, м. Київ, Україна.

Павленко М. О., канА. меА. наук, Аоцент каф. стоматології, Національна медична академія післядипломної освіти імені П. А. Шупика, м. Київ, Україна.

\section{Сведения об авторах:}

Илык Р. Р, А-р меА. наук, профессор каф. ортопедической стоматологии, Аьвовский Национальный медицинский университет имени Аанила Галицкого, Украина.

Сиренко А. Ф., канА. меА. наук, Аоцент каф. стоматологии, Национальная медицинская академия последипломного образования имени П. ^. Шупика, г. Киев, Украина. Павленко М. А., канА. меА. наук, Аоцент каф. стоматологии, Национальная медицинская академия последипломного образования имени П. ^. Шупика, г. Киев, Украина. 
References

[1] Brizuela, A., Martín, N., Fernández-Gonzalez, F. J., Larrazábal, C., \& Anta, A. (2014). Osteotome sinus floor elevation without grafting material: Results of a 2-year prospective study. Journal of Clinical and Experimental Dentistry, 6(5), e479-e484. doi: 10.4317/jced.51576.

[2] Cara-Fuentes, M., Machuca-Ariza, J., Ruiz-Martos, A., Ramos-Robles, M. -C., \& Martínez-Lara, I. (2016). Long-term outcome of dental implants after maxillary augmentation with and without bone grafting. Medicina Oral, Patología Oral Y Cirugía Bucal, 21(2), e229-e235. doi: 10.4317/medoral.21055

[3] Dhandapani, R. B., Baskaran, S., Arun, K. V., \& Kumar, T. S. (2016). Minimally invasive maxillary sinus elevation using balloon system: A case series. Journal of Indian Society of Periodontology, 20(4), 468-471. doi: 10.4103/0972-124X.194265.

[4] Schwartz, S. (2015). Short Implants. Dental Clinics of North America, 59(2), 317-328. doi: 10.1016/..cden.2014.10.008.

[5] Pohl, V., Thoma, D., Sporniak-Tutak, K., Garcia-Garcia, A., Taylor, T., Haas, R. \& Hämmerle, C. (2017). Short dental implants $(6 \mathrm{~mm})$ versuslong dental implants (11-15 mm) in combination with sinus floor elevation procedures: 3-year results from a multicentre, randomized, controlled clinical trial. Journal of Clinical Periodontology, 44(4), 438-445. doi: 10.1111/jpe. 12694 .

[6] Pieri, F., Caselli, E., Forlivesi, C. \& Corinaldesi, G. (2016). Rehabilitation of the Atrophic Posterior Maxilla Using Splinted Short Implants or Sinus Augmentation with Standard-Length Implants: A Retrospective Cohort Study. The International Journal of Oral \& Maxillofacial Implants, 31(5), 1179-1188. doi: 10.11607/jomi.4370.

[7] Esposito, M., Barausse, C., Pistilli, R., Sammartino, G., Grandi, G. \& Felice, $P$. (2015). Short implants versus bone augmentation for placing longer implants in atrophic maxillae: One-year post-loading results of a pilot randomised controlled trial. European Journal of Oral Implantology, 8(3), 257-68.

[8] Shi, J. -Y., Gu, Y. -X., Qiao, S. -C., Zhuang, L. -F., Zhang, X. -M., \& Lai, H. -C. (2015). Clinical evaluation of short 6-mm implants alone, short 8-mm implants combined with osteotome sinus floor elevation and standard 10-mm implants combined with osteotome sinus floor elevation in posterior maxillae: study protocol for a randomized controlled trial. Trials, 16, 324. doi: 10.1186/s13063-015-0853-4

[9] Pavlenko, O. V., Bida, V. I., Doroshenko, O. M., \& Sirenko, O. F. (2012). Elektromiohrafichna otsinka funktsionalnoi aktyvnosti zhuvalnykh miaziv u patsientiv z ortopedychnymy konstruktsiiamy z oporoiu na implantaty [Electromyographic activity of masticatory muscles of patients with orthopedic constructions fixed on implants]. Sovremennaya stomatologiya, 3(62), 131-134 [in Ukrainian].

[10] Doroshenko, O. \& Sirenko, O. (2017). Prediction of biomechanical complications in patients with implant supported fixed dental prostheses in different terms of functional loading. Zaporozhye medical journal, 4(103), 424-429. doi: 10.14739/2310-1210. 2017.4.104923. 